\title{
Roberto De Gaetano: impulse- images and the cinema between the forms and the forces
}

\section{Bruno Bueno Pinto Leites}

Doutorando; Universidade Federal do Rio Grande do Sul

bleites2003@hotmail.com

\section{Alexandre Rocha da Silva}

Doutor; Universidade Federal do Rio Grande do Sul arsrocha@gmail.com

\begin{abstract}
Since the early nineties Roberto De Gaetano has been working on the relationship between cinema, aesthetics and philosophy. In this interview, he talks about impulse-images, a concept among Gilles Deleuze's taxonomy that has remained someway "marginal" although being powerful for understanding a large set of problems, as the body of images, the inscription of a death drive in cinema and the conception of worlds in the act of their own destruction. We also had the opportunity to talk about De Gaetano's latest works and the difference that he establishes between the cinema of forms and the cinema of forces.
\end{abstract}

\section{Keywords}

Impulse-image. Roberto De Gaetano. Gilles Deleuze. Jacques Rancière.

Since the early nineties Roberto De Gaetano has been working on the relationship between cinema, aesthetics and philosophy. Among his books, we find important works on Gilles Deleuze's film philosophy, on the subjects of body and time in cinema, on Italian cinematography and on contemporary theories of image.

In many of his books, De Gaetano has explored Deleuze's concept of impulse-image. It is a concept from Deleuze's taxonomy of images that has remained someway "marginal", as he points out in this interview, due to its mix of references not necessarily made clear by Deleuze. Nevertheless, it is a powerful concept for understanding a large set of problems, as 
the body of images, the inscription of a death drive in cinema and the conception of worlds in the act of their own destruction. As De Gaetano says in this interview, in Deleuze's film philosophy the "impulses deconstruct and tear worlds apart".

Also important is the role of impulse-images in Deleuze's thought, because it connects his precedent work on psychoanalytical concepts with his film philosophy.

In La potenza delle immagini: il cinema, la forma e le forze, De Gaetano shows the actual stage of his own thought on cinema, by means of the analyses of form and force as two main tendencies in cinema's history. Moreover, he proposes accurate analyses on contemporary theories on cinema, art and politics, producing dialogues and exploring distances and influences in authors such as Deleuze, Jacques Rancière, Alain Badiou and Georges Didi-Huberman.

Although mostly focused in impulse-images and its implications, in this interview we also had the opportunity to talk about De Gaetano's latest works. He could then explain two of the most important ideas of La potenza delle immagini. Firstly, the difference between form and force in cinema and how it distinguishes the films of Sergei Eisenstein and Jean Epstein. Secondly, the main difference between the approach of Deleuze and Rancière regarding the image. As explains De Gaetano in this interview,

Deleuze's perspective is ontological: the image is reality at its 'origin', an identity with the thing. [...] Far from any vitalism, for him [Rancière] the question of cinema is primarily linked to the notion of the form. Rancière's thought should be inscribed within the wider 'formalist' tradition.

Roberto De Gaetano is full professor of Filmology, director of the International PhD in Humanities, Chairman of Degree Courses in Performing Arts, and he is in charge of the Audio-visual Laboratory "Raoul Ruiz" of the Department of Humanities at the University of Calabria (Italy).

Among others, he has published Il cinema secondo Gilles Deleuze (1996a), Passaggi: figure del tempo nel cinema contemporaneo (1996b), Robert Bresson. Il paradosso del cinema (1998), Il corpo e la maschera. Il grotesco nel cinema italiano (1999), Il visible cinematografico (2002), Teorie del cinema in Italia (2005), L'immagine contemporanea. Cinema e mondo presente (2010), Politica delle immagini. Su Jacques Rancière (2011), Nanni Moretti. Lo smarrimento del presente (2011), La potenza delle immagini. Il cinema, la forma e le forze (2011) and Lessico del cinema italiano. Forme di rappresentazione e forme di vita (2014). 
First of all, we would like to have an overview about your ideas on Gilles Deleuze's impulseimages. It is a chapter from L'image-mouvement that does not actualize directly the concepts of Henri Bergson, as the perception-image, the affection-image and the action-image. Besides, Deleuze does not utilize theoretical references for supporting his idea of impulse, and he prefers to not refer his precedent work on the theme, as Presentation de Sacher-Masoch, Différence et répétition and Mille plateaux.

Although a few authors have celebrated the concept of impulse-image ${ }^{1}$, and others have emphatically criticized $i^{2}{ }^{2}$, it seems to us that it has become somehow indifferent among the researches that utilize Deleuze's work. Do you agree? Do you agree that impulse-image is an idea that has had low repercussion, mainly if we consider that Deleuze's work has been important for a whole group of works that think body and cinema, as the ones of Steven Shaviro (1993), Nicole Brenez (1998) and Raymond Bellour (2009)? In this sense, it seems to us that your work is an exception among this group, and we think especially of II corpo e la maschera (1999) and the articles I/ corpo, la forma e le forze (1996c) and Le immagini del corpo fra cinema classico, moderno e contemporaneo (2006).

We should not forget one important thing. The classification of images operated by Deleuze is linked to the definition of the material states of subjectivity: perceptive, active, affective, according to a macro-classification that Deleuze takes from Bergson's Matter and Memory. As you have pointed out, the impulse comes out of the framework of Bergsonian categories but nevertheless identifies a material state of subjectivity, which Freud was elaborating in those very years (of Bergson's book and of the birth of cinema). Well, if the impulse-image is a concept that did not have the same fortune of others, this is because it is explicitly a 'mixed' concept compared to others; its signs of genesis and composition do not have the purity of perception (phenomenology), of affection (idealism), of action (pragmatism), but are intertwined with other signs, they emerge from other contexts. The 'context' (a link of editing, a narrative sequence) constitutes the sign, which distinguishes, for example, the affection-close up from the pulsional one. But it is above all a certain alteration of the structure of action, and of the world which it relates to, to transform behaviors into perversions and disseminate the situation with signs of the impulse. It is a deformation of the forms that govern our practice to bring the pulsional drive out into the world of action: the rituals of everyday behavior become obsessive, the motivated action becomes a gratuitous act, the value of the "Whole" disintegrates into the sensoriality of the "fragment". It is precisely this 'mix' to make the impulse-image on the one hand an

\footnotetext{
${ }^{1}$ As Serge Daney in Nos amies les images (1983).

${ }^{2}$ As Luc Moullet in Les vertes poubelles de Gilles Deleuze (2000).
} 
important conceptual operator to read films, but on the other resulted into its 'marginalization' within the important impact of Deleuze's classification of images.

In a recent book, La potenza delle immagini, especially at the text L'alba di un mondo, you write that cinema is a creator of worlds. From this approach, that seems related to the work of Jacques Rancière and his articulation of aesthetics and politics, we would like to ask you the following:

In Deleuze, the impulse-images are marked by negativity, death, law of steepest slope. He says that all impulses get together in the elementary impulse of death. It is evident in the movies he works with, among which we could refer Greed (Erich von Stroheim), El angel exterminador (Luis Buñuel) and Monsieur Klein (Joseph Losey).

So, if we agree that cinema creates worlds, how could we politically understand these images full of negativity?

The fact that cinema creates worlds does not mean that worlds created by cinema are protected from destruction and death. Not at all. The notion of world identifies the complexity of what cinema builds up, since compared to other artistic languages it disposes of a plurality of "media" that intertwines an iconic and narrative dimension, generating something that directly affects our desires and fears. First of all, a world identifies the place of a desired or feared "habitability", both generative or destructive. Impulses deconstruct and tear worlds apart, and a world in decay is always a world that has been created. Creation regards the shapes and their power, destruction instead relates to a stretch of content. Hence Greed is one of the great pulsional worlds created by silent film, with its "fragments" and its perversions: an endless voracity which ends up with the destruction in a 'smooth space' like the desert.

Deleuze names these "pulsional worlds", a name that defines and identifies a generic category, namely "naturalism". We hence find the lyricism of affection, the realism of action and the naturalism of the impulse. Naturalistic worlds are pulsional worlds. However, the destructiveness that characterizes them, their being 'at the mercy' of a death drive, does not exclude the fact that they have been created. 
We would like to ask you about your understanding of two concepts and their relevance in cinema studies: impulse and body without organs. When you analyze the work of Peter Greenaway in the book Passaggi: Figure del tempo nel cinema contemporaneo, it seems that the body without organs could be a characteristic of the naturalism in Greenaway ${ }^{3}$. However, in the article Le immagini del corpo fra cinema classico, moderno e contemporaneo, you say that the impulsive body is an organic body. Therefore, we would like to know how you understand these two concepts, the relationship between them and their relevance for comprehending different images in cinema.

If it's true that the impulse-image emerges from the realm created by the actionimage, and if the latter is related to the organic body intended as a support of the action itself, this means that the 'segmented body' of the impulse is organic, though belonging to a destroyed (shredded) or undone (rotting) organism. Greenaway's body - because it is eminently invested by the impulse (the woman without legs in A Zed and two Noughts that 'facilitate' the access to a sexual intercourse) - is and remains an organic body, where the part refers to the Whole and vice versa.

Intensive bodies instead, crossed by thresholds and not made of organs, are those who suspend the organic. Bodies that are 'treated' like intensive surfaces. Also, the attitudes of the body, the gestus, the daily ceremonial or dramatization which emerge from some modern cinema, define the status of a body suspended from its organicity. The 'theatralized' body is removed from its organic destiny and time; by entering in ceremony, it is only marked by a rhythm. We know what Deleuze says about the greatest difference between a racing horse and a cart horse, compared to the one between the latter and an ox. The difference for categories and species is secondary compared to the one for intensity. And we might add, along the lines of some great film theorists (from Eisenstein to Rancière): the difference between a literary text and a film is often less significant than that between two films. There is less difference between Bernanos and Bresson than between Bresson and Spielberg.

\footnotetext{
3 "Il ventre dell'architetto, come tutto il cinema di Greenaway, è popolato ed attraversato da organi senza corpo e da corpi senza organi che segnano e mettono in gioco la grande voragine dell'identità del soggetto." (DE GAETANO, 1996b, p. 83).
} 
The Musée d'Orsay in Paris recently held an exposition about Marques de Sade, which focused mostly in showing his large influence in the arts of the nineteenth and the beginning of the twentieth centuries. Throughout the exposition, there were many works exploring perversions, cannibalism, death and other aspects that recur in the universe of impulseimages. What influence had Sade in Deleuze's work? Do you think this influence is still present in the proposition of an impulse-image?

We know that Deleuze's analysis of sado-masochism in Présentation de Sacher-Masoch is entirely centered around the question of the law, on the possibility of crossing and suspending it in name of a higher principle (this is sadism), or to measure its consequences and effects in terms of humor (this is masochism). Within this 'theatre of the law', and its questioning, we can hence understand sado-masochism. But in L'image-temps the impulseimage is defined without crossing explicitly the issue of the law (and its related placements): the impulse is a material state of subjectivity, nothing more than that. Deleuze distinguishes the 'nature' of impulses, which can be either 'elementary' or 'complex', from the object of impulses, the 'piece' or 'partial object', and the 'fate of impulses', which is to take over everything in their path. More explicitly, we rather find analogies in the essay on Zola et la felure, rather than that on Sade. We find more analogies on the side of the 'naturalness' of instincts and their inheritance ('L'hérédité n'est pas ce qui passe par la felûre, elle est la felûre elle-mêmê'): 'A travers la felûre, l'instinct cherche l'objet qui lui correspond dans les circostances historiques et sociales de son genre de vie'.

These analogies with the pulsion-image are obvious: there is neither irony nor humor nor law, but the relentless push to destruction - the death drive which Freud elaborated in Beyond the Pleasure Principle - that characterizes 'naturalism' from Zola to Erich von Stroheim, up to Greenaway. 
In La potenza delle immagini you affirm that cinema must be understood according to the relations between form and force. The form is in connection with the representative regime of arts, with Hollywood, but also with Sergei Eisenstein. On the other hand, the force is made of immanent images related to the aesthetic regime of arts, in which you include Jean Epstein.

We would like to ask you about the role of Eisenstein as a filmmaker and a theoretician of form, because he was someone passionately interested in this matter. We think, for example, of his analyses of non-objective landscapes in El Greco or the fluidity of forms in Giovanni Piranesi. That being said, how could we understand the whole work of Eisenstein about the ecstasy and the nonindifferent nature regarding to the paradigm of form and to the representative regime of arts?

This is an important point, because it allows us to focus on a crucial issue in thinking of art and cinema, that is the relationship between the work of the form and what exceeds it, what leads to the outside, to that whole energy which the form is precisely able to shape. Now, there are authors and theorists, among them Eisenstein, who were able to bring the notion of form to its limit (the concept of 'ecstasy') by grounding it in the horizon of life, outside of which the form would only be a sterile procedure. The metaphor of the protoplasm, that Eisenstein uses to explain a process of construction open to the horizon of the possible, effectively defines a vital and dynamic conception of the form. A conception in which the structure of the work (the 'organicity', as called by Eisenstein) does not get completely dissolved. However, when the form 'dissolves' itself, having to cope with the pressure of inexorable forces, then the image ceases to be a formal compound and becomes a 'collection of forces' (Deleuze).

Epstein here represents the other side of Eisenstein. In Epstein, forces come to question even the perceptual integrity of images. Things on the screen are part of a becoming that causes them to lose all identity; they are marked by an intensive molecularity that challenges every form: 'Say: red, soprano, sweet, perfume, and instead there is nothing but speed, movements, vibrations'. Such intensity radically destroys the organic unity of the work, while for Eisenstein, although being 'ecstatic', the work should always have an organic texture. 
We would like to ask you about your understanding of narrative in cinema. In La potenza delle immagini you write that "La piega mimetica del cinema, quella che lo ha orientato verso il racconto di storie, gli ha fatto 'mancare' la sua 'esteticita'" (p.107). Therefore, is the narrative part of the representative regime in cinema? In this point of view, does the narrative, the storytelling, prevent cinema of achieving its aesthetical potentialities?

No, but I believe that what we call narrative is a 'derivative', as Deleuze says, and not a structural element of the movement-image. This is what also Rancière believes, according to a different perspective of course, when he opens La fable contrasté by quoting Epstein, and when he traces one of the signs of the 'aesthetic regime' to the gap between the visible and the speakable dimension of the image.

Deleuze's perspective is ontological: the image is reality at its 'origin', an identity with the thing (according to Bergson's meta-theoretical assumptions). The narrative dimension operates a 'selective' process on this 'primal' identity. This process is secondary to the dimension of the matter-image, although this 'secondary' process is the gateway to that very dimension. The 'dimension of immanence' will be accessible only through questioning narrative and representative linearity.

Rancière's perspective is instead aesthetic and political: the image is neither reality nor nature, but it is a construct. And primarily it is a construct of editing, which concerns the connection between the visual and verbal dimension of the image. Pointing to the difference between these two dimensions firstly means questioning the subordination of the visual to the verbal, the dismissal of the centrality of the dramatic to the benefit of the 'tragedie en suspens', as mentioned by Epstein. That is, the identity of the sensible and the intelligible that discards the mythos, giving centrality to the 'unfinished' of life. 'La vie ne connaît pas d'histoires. Elle ne connaît pas d'actions orientées vers des fins - Rancière says by paraphrasing Epstein - mais seulement des situations ouvertes dans toutes les directions'. If this is true, by inheriting a certain aesthetic tradition (literary in particular), cinema must be able to build an alternative model to the representative one.

The difference is clear: for Rancière, at a given time in the history of aesthetics (mainly from Schiller), the mimetic logic (linked to the notion of likelihood of the Aristotelian mythos) has entered into a crisis and was replaced by the identity of 
passive and active, of matter and form, of sensible and intelligible, that characterizes the 'aesthetic regime'; for Deleuze, this identity (which takes the form of identity between matter and image) defines the ontological status of the image tout court, which, under certain conditions (for example in the so-called modern cinema), has emerged more strongly.

Logical expression of a level of immanence (Deleuze), the logic of composing an aesthetic level (Rancière): this is the greatest difference.

Finally, we would like to ask you about the ensemble of your work and your main influences. It seems to us that your work in the 90 's is remarkably Deleuzean, while more recently, without leaving his influence aside, it includes other authors in the same plane of importance. We think mostly of Rancière.

Your division between form and force seems to be in a close dialogue with Rancière's thought, his concepts of the aesthetic and representative regimes in permanent conflict in the field of cinema. In Deleuze, the problem of form does not have the role and the potential of demarcation. Filmmakers as Dziga Vertov, Jean Epstein and Stan Brakhage are included in the sphere of the movement-images.

Therefore, in a large sense, we would like to ask you about your relation with the work of your main influences and its evolution during your trajectory, especially Deleuze e Rancière. Moreover, we would like to know how your last book rebounds the evolution of these relations. Do you agree that it reveals a growing influence of Rancière? Do you agree that in a sense it challenges Deleuze's classification of images?

On the one hand, with L'image-mouvement and L'image-temps Deleuze traced cinema back to the great tradition of 'vitalism' (under the power of the forces). This tradition has found in Bergson's Matter and Memory an absolute point of reference at the turn of the Nineteenth century; hence cinema intended as a great expression of life in all its forms, both actual and virtual. On the other hand, he has built a 'classification' of images, unique for its richness and complexity, at a time of great transformation for cinema (which Deleuze also emphasizes in the preface to Serge Daney's Ciné-journal). A classification brought about as if to 'seal' a moment of transition (rather than of ending) of cinema, through a work essentially coeval - although different - to Godard's Histoire $(s)$ du cinéma: the construction of a taxonomy of film images, in a moment in which cinema seemed to return to its past. The effect of Deleuze's work was to make cinema more alive than ever, not only by re-actualizing the past, but also by identifying a sort of 'natural' codification of images in a transhistorical form (Pasolini's Ur-code). 
In Rancière something else is at stake. Far from any vitalism, for him the question of cinema is primarily linked to the notion of the form. Rancière's thought should be inscribed within the wider 'formalist' tradition (as Badiou calls it). At stake here is not the ontological founding of cinema (the assertion of its identity within the horizon of life), but the understanding of how cinema has inscribed a radical transformation of the forms in its own device. A transformation which, starting from the second half of 19th century, has brought about the abandonment of a mimetic horizon in order to approach an aesthetic one (with all the consequences entailed). Cinema played a decisive role within this transformation of the 'partage du sensible', which has also caused a process of 'democratization' of the forms.

Therefore, ontology or aesthetics of cinema, expression of forces or composition of forms: something very important seems to be at stake in both cases. That is: a new image of thinking. An image removed from voluntarism and activity, directly inscribed into things and in their 'silence', in matter and in its pure light; ultimately in cinema's automatism, in cinema as the 'spiritual automaton', as the identity of the passive and the active.

\section{References}

BELLOUR, Raymond. Le corps du cinéma. hypnoses, émotions, animalités. Paris: P.O.L., 2009.

BRENEZ, Nicole. De la figure en général et du corps en particulier: l'invention figurative au cinéma. Bruxelles: De Boeck Université, 1998.

DANEY, Serge. Nos amies les images. Libération, Paris, 3 out 1983.

DE GAETANO, Roberto. Passaggi: figure del tempo nel cinema contemporaneo. Roma: Bulzoni, 1996b.

DE GAETANO, Roberto. Il cinema secondo Gilles Deleuze. Roma: Bulzoni, 1996a.

DE GAETANO, Roberto. Il corpo e la maschera. Il grottesco nel cinema italiano. Roma: Bulzoni, 1999.

DE GAETANO, Roberto. Il corpo, la forma e le forze. De Gaetano, Roberto (Org.). La visione e il concetto : Scitti in omaggio a Maurizio Grande. Roma: Bulzoni, 1996c.

DE GAETANO, Roberto. Il visibile cinematografico. Roma: Bulzoni, 2002.

DE GAETANO, Roberto. L'immagine contemporanea. Cinema e mondo presente. Veneza: Marsilio, 2010. 
DE GAETANO, Roberto. La potenza delle immagini. Il cinema, la forma e le forze. Pisa: ETS, 2012.

DE GAETANO, Roberto. Le immagini del corpo fra cinema classico, moderno e contemporaneo. In: D`ANGELA, Toni. Corpo a corpo : il cinema e il pensiero. Gennaio: Falsopiano, 2006.

DE GAETANO, Roberto. Lessico del cinema italiano. Forme di rappresentazione e forme di vita. Sesto San Giovanni: Mimesis, 2014.

DE GAETANO, Roberto. Nanni Moretti. Lo smarrimento del presente. Cosenza: Pellegrini, 2011.

DE GAETANO, Roberto. Robert Bresson. Il paradosso del cinema. Roma: Bulzoni, 1998.

DE GAETANO, Roberto. Teorie del cinema in Italia. Calabria: Rubbettino, 2005.

DE GAETANO, Roberto. Politica delle immagini. Su Jacques Rancière. Cosenza: Luigi Pellegrini, 2011.

MOULLET, Luc. Les vertes poubelles de Gilles Deleuze. La lettre du cinéma, n. 15, 2000.

SHAVIRO, Steven. The cinematic body. Minneapolis: University of Minnesota, 1993.

\section{Roberto De Gaetano: imagens-pulsão e o cinema entre as formas e forças}

\section{Resumo}

Desde o início dos anos 1990, Roberto de Gaetano trabalha acerca da relação entre cinema, estética e filosofia. Nesta entrevista, ele fala sobre as imagens-pulsão, um conceito da taxonomia de Gilles Deleuze que permaneceu de alguma forma "marginal", mesmo sendo potente para compreender um amplo grupo de problemas, como o corpo da imagem, a inscrição de uma pulsão de morte no cinema e a concepção de mundos no ato de sua própria destruição. Nós também tivemos a oportunidade de conversar sobre os trabalhos mais recentes de De Gaetano e a diferença que ele estabelece entre o cinema das formas e o cinema das forças.

\section{Palavras-chave}

Imagem-pulsão. Roberto De Gaetano. Gilles Deleuze. Jacques Rancière. 